\title{
Challenges Facing Female Physicians in Egypt
}

\author{
Fayssal Mostafa Farahat*
}

Abstract: Background: Female physicians allover the world have grown considerably and yet little is known about these women. Objectives: This study was conducted to explore challenges faced by Egyptian female physicians as they pursue their careers and different ways of coping with these challenges. Methods: Identification of challenges faced by the study participants was done through self administered questionnaire including both open and closed ended questions. It included relevant personal details, work characteristics, social circumstances, career development choices and opportunities, family life achievements, and barriers, and personal goals. Results: Total number of participants was 300 female physicians. Their mean age was 31.09 years. Most of them were married $(76.7 \%)$, and $40 \%$ of the families were dual-doctor (both partners are physicians). Fifty-three percent of participants were clinicians, $22 \%$ academicians, and $25 \%$ house officers. Challenges reported by physicians were either work- or family-related. While overt discrimination was rare, many complained of subtle forms of bias. All participants reported that balancing work and family was more difficult than they ever expected. Participating physicians have dealt with challenges in different ways including: decision of small family size (82.3\%), recruitment of babysitter/housekeeper $(76.3 \%)$, and sharing in family income (62.0\%). Conclusion: Physician training programs, workforce policy, and public expectations should recognize and adapt to the diverse and changing needs of physicians.

\section{INTRODUCTION}

Women around the world have moved into industry and service sector in increasing numbers $^{(1)}$. In the past 20 years, although the number of female physicians allover the world has grown considerably, yet little is known about these women, their current job perceptions or about contemporary factors associated with satisfaction with medical practice $^{(2)}$ especially in non-western countries. In Egypt, female physicians constitute nearly $25 \%$ of the total number of physicians ${ }^{(3)}$, and during the past 5 years, about $35 \%$ of medical school graduates were women $^{(4)}$. After graduation from the medical school, physicians spend one year as house officers rotating at different departments, then they apply for residency program (36 months). Those who did not have the opportunity to join residency program, work as general practitioners at different primary

*Community Medicine and Environmental Health Department, Faculty of Medicine, Menoufia University, Egypt 
healthcare units. By the end of the residency program, a physician should finish his Master Degree in Medicine (MSc) to be promoted into specialist. Consultants should have Medical Doctorate (MD) degree, a program that can be applied for after the master degree and on average it continues for four years. Physicians after graduation or finishing their residency program may choose to apply for a position to work as research assistant at any of the academic or clinical medical departments of the faculty of medicine; respectively. They have also to finish MD in their specialty to be promoted as a faculty member. Although academicians do not have any contacts with patients, faculty member clinicians continue their clinical practice.

Female physicians are in a more challenging situation than their male counterparts. They are taking care not only of their full-time jobs, but also of their homes ${ }^{(5,6)}$. Results of a survey study reported that $23 \%$ female obstetricians-gynecologists aged less than 40 years have reduced their hours or stopped practice altogether for an extended period of time to meet family needs ${ }^{(7)}$. Potee et al., ${ }^{(8)}$ showed that $85 \%$ of married women physicians do more of the cooking, laundry, child care, and shopping than their spouses. However, this situation is more exaggerated in eastern cultures (e.g., Egypt), where taking care of homes is still considered the main responsibility of women with a little sharing of their husbands. Women usually work at least as hard as their male counterparts, but face more on-the-job pressure from colleagues, work load, and patients ${ }^{(1)}$.

In Egypt as in many other countries, female physicians work in public and private health units, taking shifts in hospital emergency departments, performing surgeries, establishing their own private practices, and teaching medical students ${ }^{(9)}$. Although most female physicians indicate that they are generally satisfied with their careers $^{(10)}$, the multiple identities of these professional women and their lived experiences can result in various challenges in family and career life ${ }^{(5)}$.

To the extent of our knowledge, no recent, comprehensive studies have been done of correlates of family and career challenges among female physicians in this part of the world. Therefore, this study was 
conducted to explore the challenges faced by

Egyptian female physicians as they pursue their careers and different ways of coping with these challenges.

\section{MATERIAL AND METHODS}

Menoufia Governorate - the designated area of the study - is located at the delta region, northern Egypt and consists of 9 districts. It includes one university hospital, one teaching hospital, eight district hospitals in addition to the rural primary healthcare units that are distributed throughout the governorate. While the university hospital belongs to Ministry of Higher Education, the teaching hospital, district hospitals and primary healthcare centers belong to Ministry of Health $(\mathrm{MOH})$.

This study was conducted during the period from March to September 2004. It was conducted at Menoufia Faculty of Medicine and university hospitals, the teaching hospital, 3 randomly selected district hospitals, and 6 randomly selected primary healthcare units.

The target population of female physicians is defined as those who have received formal university medical education and are practicing their profession in one of the governmental health centers. All potential study candidates were contacted via their work place. Approval of the Menoufia University Institutional Review Board (IRB) was obtained to conduct the study as well as the director of each study area who gave permission for the study to be undertaken.

Identification of challenges faced by the study participants was done through self administered questionnaire including both open and closed ended questions. To develop the questionnaire, a focus group discussion was administered and included ten physicians working at the university hospital, teaching hospital, and primary care centers. Two physicians were randomly selected to represent each of the academic, surgical, non-surgical, house officers, and primary health care centers. The focus group aimed at identifying the most common problems, constraints, and difficulties faced by the Egyptian female physicians as well as methods that are commonly used to cope with the challenges. Literature review was performed to include other challenges reported in previous studies. A pilot study 
was conducted on other ten randomly (afternoon or night). Shift work was selected

selected female physicians to test the validity

of the developed questionnaire. Both focus group and pilot study participants were excluded from the study. Themes covered in the questionnaire included: relevant personal details, work characteristics, social circumstances, career development choices and opportunities, family life achievements and barriers and personal goals.

For each specified challenge (work, career or family-related), participants were asked to assess its magnitude from their personal point of view, whether they perceive it as high, moderate, or low.

Questionnaires with serial numbers were distributed in sealed envelops through the secretary of each department to all female physicians. Each physician was asked to return back the completed questionnaire to the secretary office of each department in another sealed envelop and not to mention their names on it. Completing the questionnaire and returning it back was considered as a consent.

Study participants were compared based on their assignment for work in shifts as a major contributing factor that affects the significance and magnitude of challenges faced by physicians.

\section{Statistical Analysis}

Data were collected and statistically analyzed using SPSS statistical package version 13. Chi-square test was used to compare the perception (as low, moderate, and high) of shift and non-shift work physicians regarding each specified challenge. Level of significance was determined at $P<0.05$.

\section{RESULTS}

\section{Personal and work-related characteristics}

Three hundred female physicians participated in the study. Among those working in the university hospitals, the response rate was $76.7 \%$ (185 out of 232 female physicians), compared to $85.9 \%$ (67 out of 78 female physicians) from the $\mathrm{MOH}$ teaching hospital and $87.3 \%$ (55 out of 63 female physicians) from the selected district hospitals and primary healthcare units.

Age of participants ranged from 25-55 years with mean $\pm S D$ of $31.09 \pm 6.46$. Most participants were married (76.7\%). Female 
physicians' partners were all professionals (40.4\% medical and $59.6 \%$ non-medical). Mean number of children was two with a maximum number of 5 children. Hundred and eighty-six participants (62.0\%) have only Bachelor degree in medicine (i.e., MBBCh), $71(23.7 \%)$ have master degree (i.e., MSc), and $43(14.3 \%)$ have doctorate degree in medicine (i.e., MD) (Table 1).

About fifty-three percent of participants were clinicians, 65 physicians (21.7\%) were academics (i.e., working in the academic basic science departments at the Faculty of Medicine, Menoufia University), and 75 $(25.0 \%)$ were house officers. Most clinicians $(68.8 \%)$ worked in non-surgical departments including laboratories, $17.4 \%$ in different surgical departments, $11.3 \%$ in radiodiagnosis and radiotherapy departments, and only $2.5 \%$ were anesthesiologists (Table 1 ). The most common clinical specialties were pediatrics, dermatology, clinical pathology, and gynecology. Twenty percent of the participants worked in the private sector beside their regular governmental (public) work. According to the Egyptian Ministry of Health regulations, physicians can work in their own private clinics or other private hospitals after regular working hours (8:00 AM - 3:00 PM) six days per week.

All academics have no shift work, while all house officers $(n=75)$ and $75 \%$ of the clinicians $(n=120)$ are assigned to work in afternoon and night shifts (Table 1).

Challenges reported by participants were divided into either work-related (including career development) or family-related challenges (Table $2 \& 3$ ).

\section{Work -related challenges}

Work-related challenges reported by the study participants and their perceptions are reported in table (2). Percentages of shift work physicians who rated the reported challenges as high were significantly more than non-shift work physicians in four out of six reported challenges (i.e., possibility of holding decision making posts, work-related stress, cultural perception of community toward medical women specialty, and graduate studies opportunities $(p=0.001)$. On the other hand, Obedience from paramedicals and workers to instructions of female physicians was considered as lower compared to their male counterparts and it 
was rated as high challenge by a significant higher percentage of non-shift work physicians $(p=0.001)$. Despite percentage of shift work physicians who rated difficulties of application of maternity leave benefits as high challenge was more than non-shift work physicians, the difference was not statistically significant $(p=0.08)$.

\section{Family-related challenges}

Balancing family life and career development, appropriate caring of children and satisfactory housekeeping activities have been reported as high challenges by significantly higher percentages of shift work physicians than non-shift work physicians (76\% vs. $64.8 \% ; 73.7 \%$ vs. $57.2 \%$, and $72.8 \%$ vs. $55.2 \%$, respectively). Differences were statistically significant $(p<0.05)$. On the other hand, percentages of shift and non-shift participants who rated the understanding from husband towards nature of their work as high (18.5\% and $11.3 \%$, respectively) were significantly lower than those who rated it as low challenge $(41.0 \%$ and $64.9 \%$, respectively) (Table 3).

\section{Methods of coping with challenges}

Participating physicians have dealt with different challenges in different ways. The most common methods were: decision of small family size (82.3\%), recruitment of babysitter/ housekeeper (76.3\%), sharing in the family income $(62.0 \%)$, followed by selection of potentially non-emergency or controllable lifestyle specialties (e.g., academia, dermatology, laboratory) (34.3\%), living near the place where they work (physicians may choose to live in the houses that are attached to most primary healthcare units) (21.0\%), and taking unpaid vacation (15.7\%) (Table 4). Methods of coping with challenges did not significantly differ between shift and non-shift work physicians except for selection of potentially non-emergency specialty that was significantly higher among non-shift women $(68.9 \%)$ as compared to those working in shifts $(31.07 \%)(p=0.001)$ (Table 4).

\section{DISCUSSION}

The multiple identities of female physicians, as professionals, leaders, coworkers, parents and postgraduate students, can put pressure on these women ${ }^{(9,11)}$. Trying to play out their many roles at any one time 
can inevitably lead to tension and potential conflict $^{(5)}$. In Egypt, challenges may be different or even more than those reported in western countries due to differences in sociocultural circumstances.

Overall, in the current study, shift work physicians faced more challenges as compared to non-shift work physicians. Possibility of holding decision making post has been ranked as the first high work-related challenge by both shift and non-shift work participants. Kværner et al.,(11) reported that probability of women's achieving senior positions seems to increase with the proportion of women in the specialty and in academic departments with regular working hours that fit in with family responsibilities. This challenge may be more exaggerated in a country like Egypt where cultural factors have general low esteem towards women leadership.

Work-related stress in the current study has been reported by shift-work physicians as the second highest challenge. Feeling overloaded, amount of overwork, and time on call have been reported by several authors $^{(9,12-14)}$ as the most common sources of stress among physicians. It is obvious that these sources are associated with working in shifts. Moreover, social circumstances and life events outside the workplace including marriage and children have contributed to stress in physicians ${ }^{(13,15)}$. However, it has been suggested that overload may partly reflect the quality of teamwork that female physician's experience ${ }^{(16)}$, especially in communities where some traditional barriers may still limit working with females in teams. Other factors reported to be associated with stress in this occupational group include dealing with patients' suffering, death, emergencies, complaints, and litigation, being poorly managed or resourced, as well as personality traits - such as a high level of self criticism $^{(17) .}$

Application of maternity leave benefits (i.e., taking paid and/or unpaid vacation) has been reported as high challenge by both shift and non-shift work physicians. According to the Egyptian law, working women are allowed to take paid maternity leave for 3 months after delivery, and any other vacation for the child care will be unpaid(18). Some female physicians prefer to return back to work even 
before the end of the paid maternity leave more feasible for non-shift work physicians as because this leave will affect their they may have enough time and most of them postgraduate studies (e.g., MSc, Diploma, are academicians, so part of their regular MD) and career development and/or the work is performing research and teaching family income will be affected by the leave thereafter especially if they are working in private clinic or hospital. Establishment of suitable professional daycare centers/units within the health facilities may be an alternative relieving stress arises from balancing maternity responsibilities and career development.

Although the eastern community in general respects being a physician, its perception towards leaving families (especially young children) because of shift work is alternatively negative ${ }^{(19)}$, which can explain why shift work physicians in this study reported cultural perception of the community towards medical specialty as a high challenge.

Postgraduate studies opportunities is another challenge reported by higher percentage of shift compared with non-shift work physicians. Although this may be a challenge that faces both groups, postgraduate studies opportunities may be medical students. On the other hand, shift work physicians (all of them are clinicians) spend most of their regular daily activities dealing with patients and may not have enough time for studying, unless applied for non-paid vacation.

Balancing family life and career development was the highest family related challenge. In similar studies ${ }^{(5,14,20)}$, married physicians reported that this balance is more difficult than they ever expected. The present study supports the findings of others ${ }^{(6,21)}$ who reported caring of children and satisfactory housekeeping as significant high challenges. Meanwhile, researchers ${ }^{(7,22)}$ noticed that as the number of children increases, physicians prefer successful family life than growing career. Egyptian medical students usually graduate at 24 years old, and this is the average age of marriage among Egyptian females. So, 5-6 years after graduation, they should have children at an age that requires close caring. This is supported with the 
present finding that most of female appeared to have a modest challenge effect

participants were married (76.7\%). However, including house officers in this study may skew data towards those who do not face family challenges yet or do not have enough experience.

The decision to pursue a specialty or not, creates a distinctive challenge within the medical profession. Non-specialists are stigmatized and possibly seen as inferior ${ }^{(20)}$. Although factors determining career choice have been reported in previous studies ${ }^{(19,20)}$ (e.g., parental encouragement or directive, family example, personal desire, social hierarchy and physical geographic location), it is appeared in this study similar to Potee et al.,(8) that large number of non-shift work physicians selected potentially nonemergency specialties including being an academician. Moreover, some of the participating physicians reported that they reassessed their career goals given their family and household circumstances and thus their career development may appear to be constrained.

In the current study, understanding of husbands of their wives' nature of work especially among shift work physicians. This finding may be attributed to the fact that all husbands were professionals. Similar explanation was reported by Fortinsky et al., (21). However, husband's support may be affected by taking shifts which may add load on the family. The current study reported that $40 \%$ of husbands were also physicians, similar to other studies ${ }^{(21,22)}$. This relatively significant percentage requires further researches to determine how physicians in dual-doctor families differ from other physicians in their professional and family lives and whether these differences are pronounced more by women than men.

Most of the coping methods that have been tried by the participating physicians were directed at the family-related challenges. Participants chose to have small family size and recruitment of babysitter or housekeeper as a relieving house and child caring strategy followed by voluntary participation in family income. Sharing in the family income would be a factor to get family support. Although women's work is important for self-esteem and for community benefits, 
traditional perceptions especially of rural Egyptian female physicians are mainly communities assume that men have the complete responsibility to met all family needs, and women do not have to share in the family income (i.e., her participation is voluntary).

Although this study covered women working in various healthcare facilities in Egypt (i.e., university hospitals and Ministry of Health teaching hospitals, district hospitals and primary care centers), Menoufia Governorate is considered a relatively rural community, where socio-cultural factors and lifestyle pattern may be different as compared to other more urban Egyptian cities. Furthermore, because this study is dependent on self-reported measures, response bias is a limitation and because of the cross-sectional nature of the study, we are not able to study physician coping methods to decrease challenges they are facing, this would require a study of longitudinal design.

Findings of the current study suggest related to socio-cultural circumstances that require better community understanding towards women medical specialty. Female medical leadership should be encouraged in different medical specialists and female mentors ${ }^{(23)}$ should take their roles in directing and sharing their experiences with young physicians. Finally, the present findings may inform policies and plans for physician training and employment. Physician training programs and workforce policy should recognize and adapt to the diverse and changing needs of physicians - especially the young - to balance professional and family roles. Medical centers must develop ways to support their faculty's efforts to combine two of the noblest pursuits-doctoring and parenting. Further studies are to be implemented in other Arab countries (e.g., Saudi Arabia) where socio-cultural circumstances may play an extensive role adding more barriers on medical women's progress.

that challenges faced by this group of 
Table 1: Socio-demographic Characteristics of the Participating Female Physicians

\begin{tabular}{|c|c|}
\hline \multicolumn{2}{|l|}{$\begin{array}{l}\text { Variable } \\
\end{array}$} \\
\hline $\begin{array}{l}\text { Age; } \\
\leq 25 \text { y } \\
25-35 \text { y } \\
\geq 35 \text { y } \\
\text { Mean } \pm \text { SD (Range) } \\
\text { - Marital Status; } \\
\text { Married } \\
\text { Single } \\
\text { - Husband's profession; } \\
\text { Medical } \\
\text { Non-medical } \\
\text { - Number of children; } \\
0 \\
1 \\
2 \\
3 \\
4 \text { or more* } \\
\text { - Medical degree } \\
\text { Bachelor (MBBCh) } \\
\text { Master (MSc) } \\
\text { Doctorate of Medicine } \\
\text { - Type of work; } \\
\text { 1. Academic } \\
\text { 2. Clinical } \\
\text { 3. House officers } \\
\text { - Specialty; } \\
\text { Non-surgical } \\
\text { Surgical } \\
\text { Radiology } \\
\text { Anesthesia } \\
\text { - Shift work } \\
\text { No } \\
\text { Yes }\end{array}$ & $\begin{array}{l}37(12.3) \\
192(64) \\
71(23.7) \\
31.09 \pm 6.46(25-55 \text { ys }) \\
230(76.7) \\
70(23.3) \\
\\
93(40.4) \\
137(59.6) \\
19(8.3) \\
84(36.5) \\
53(23.0) \\
41(17.8) \\
33(14.3) \\
186(62.0) \\
71(23.7) \\
43(14.3) \\
\\
65(21.7) \\
160(53.3) \\
75(25) \\
206(68.8) \\
52(17.4) \\
34(11.3) \\
8(2.5) \\
105(35) \\
195(65)^{\star *} \\
\\
\\
\\
\\
\end{array}$ \\
\hline
\end{tabular}


Table 2: Work-related challenges and perception of the participating female physicians

\begin{tabular}{|c|c|c|c|c|c|c|c|c|}
\hline \multirow{2}{*}{$\begin{array}{l}\text { Work-related } \\
\text { Challenges }\end{array}$} & \multicolumn{3}{|c|}{$\begin{array}{l}\text { Perception of physicians } \\
\text { with shift work } \\
(n=195)\end{array}$} & \multicolumn{3}{|c|}{$\begin{array}{l}\text { Perception of physicians } \\
\text { without shift work } \\
(n=105)\end{array}$} & \multirow[t]{2}{*}{$x^{2}$} & \multirow[t]{2}{*}{$P$ value } \\
\hline & $\begin{array}{l}\text { High } \\
\text { N (\%) }\end{array}$ & $\begin{array}{c}\text { Moderate } \\
\text { N (\%) }\end{array}$ & $\begin{array}{l}\text { Low } \\
\text { N (\%) }\end{array}$ & $\begin{array}{l}\text { High } \\
\text { N (\%) }\end{array}$ & $\begin{array}{c}\text { Moderat } \\
\text { e } \\
\mathbf{N}(\%)\end{array}$ & $\begin{array}{l}\text { Low }^{*} \\
\text { N (\%) }\end{array}$ & & \\
\hline 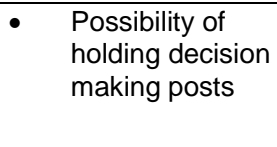 & $\begin{array}{c}156 \\
(80.0)\end{array}$ & $\begin{array}{c}27 \\
(13.8)\end{array}$ & $\begin{array}{c}12 \\
(6.2)\end{array}$ & $\begin{array}{c}43 \\
(41.0)\end{array}$ & $\begin{array}{c}32 \\
(30.5)\end{array}$ & $\begin{array}{c}30 \\
(28.5)\end{array}$ & 33.5 & 0.001 \\
\hline $\begin{array}{l}\text { Work related } \\
\text { stress (feeling } \\
\text { overloaded, } \\
\text { time on call, } \\
\text { risky specialty). }\end{array}$ & $\begin{array}{c}134 \\
(68.7)\end{array}$ & $\begin{array}{c}35 \\
(18.0)\end{array}$ & $\begin{array}{c}26 \\
(13.3)\end{array}$ & $\begin{array}{c}30 \\
(28.5)\end{array}$ & $\begin{array}{c}54 \\
(51.4)\end{array}$ & $\begin{array}{c}21 \\
(20.1)\end{array}$ & 35.4 & 0.001 \\
\hline $\begin{array}{l}\text { Difficulties } \\
\text { application of } \\
\text { maternity leave } \\
\text { benefits }\end{array}$ & $\begin{array}{c}110 \\
(56.4)\end{array}$ & $\begin{array}{c}43 \\
(22.1)\end{array}$ & $\begin{array}{c}42 \\
(21.5)\end{array}$ & $\begin{array}{c}42 \\
(40.0)\end{array}$ & $\begin{array}{c}34 \\
(32.4)\end{array}$ & $\begin{array}{c}29 \\
(27.6)\end{array}$ & 5.02 & 0.08 \\
\hline $\begin{array}{ll} & \text { Cultural } \\
\text { perception of } \\
\text { community } \\
\text { toward medical } \\
\text { women } \\
\text { specialty. }\end{array}$ & $\begin{array}{c}81 \\
(41.5)\end{array}$ & $\begin{array}{c}65 \\
(33.3)\end{array}$ & $\begin{array}{c}49 \\
(25.2)\end{array}$ & $\begin{array}{c}19 \\
(18.1)\end{array}$ & $\begin{array}{c}42 \\
(40.0)\end{array}$ & $\begin{array}{c}44 \\
(42.0)\end{array}$ & 14.3 & 0.001 \\
\hline $\begin{array}{ll} & \text { Graduate } \\
\text { studies } \\
\text { opportunities }\end{array}$ & $\begin{array}{c}79 \\
(40.5)\end{array}$ & $\begin{array}{c}65 \\
(33.3)\end{array}$ & $\begin{array}{c}51 \\
(26.2)\end{array}$ & $\begin{array}{c}18 \\
(17.1)\end{array}$ & $\begin{array}{c}35 \\
(33.3)\end{array}$ & $\begin{array}{c}52 \\
(49.6)\end{array}$ & $\begin{array}{c}16.0 \\
2\end{array}$ & 0.001 \\
\hline $\begin{array}{l}\text { - Less obedience } \\
\text { from } \\
\text { paramedicals } \\
\text { and workers }\end{array}$ & $\begin{array}{c}53 \\
(27.2)\end{array}$ & $\begin{array}{c}102 \\
(52.3)\end{array}$ & $\begin{array}{c}40 \\
(20.5)\end{array}$ & $\begin{array}{c}41 \\
(39.0)\end{array}$ & $\begin{array}{c}23 \\
(22.0)\end{array}$ & $\begin{array}{c}41 \\
(39.0)\end{array}$ & 19.7 & 0.001 \\
\hline
\end{tabular}

${ }^{*}$ low or not considered as a challenge 
Table 3: Family-related challenges among the participating female physicians

\begin{tabular}{|c|c|c|c|c|c|c|c|c|}
\hline \multirow{2}{*}{$\begin{array}{l}\text { Family-related } \\
\text { challenges }\end{array}$} & \multicolumn{3}{|c|}{$\begin{array}{c}\text { Perception of physicians with } \\
\text { shift work } \\
(n=195)\end{array}$} & \multicolumn{3}{|c|}{$\begin{array}{l}\text { Perception of physicians } \\
\text { without shift work } \\
(n=105)\end{array}$} & \multirow{2}{*}{$x^{2}$} & \multirow[t]{2}{*}{$\begin{array}{c}P \\
\text { value }\end{array}$} \\
\hline & $\begin{array}{c}\text { High } \\
\mathbf{N}(\%)\end{array}$ & $\begin{array}{c}\text { Moderate } \\
\text { N (\%) }\end{array}$ & $\begin{array}{l}\text { Low } \\
\text { N (\%) }\end{array}$ & $\begin{array}{l}\text { High } \\
\text { N (\%) }\end{array}$ & $\begin{array}{c}\text { Moderate } \\
\text { N (\%) }\end{array}$ & $\begin{array}{l}\text { Low }^{*} \\
\mathbf{N}(\%)\end{array}$ & & \\
\hline $\begin{array}{l}\text { - Balancing family life } \\
\text { and career } \\
\text { development }\end{array}$ & $\begin{array}{c}148 \\
(76.0)\end{array}$ & $\begin{array}{c}47 \\
(24.0)\end{array}$ & $\begin{array}{c}0 \\
(0.0)\end{array}$ & $\begin{array}{c}68 \\
(64.8)\end{array}$ & $\begin{array}{c}24 \\
(22.9)\end{array}$ & $\begin{array}{c}13 \\
(12.3)\end{array}$ & 13.9 & 0.001 \\
\hline $\begin{array}{l}\text { - Appropriate caring } \\
\text { for children } \\
\end{array}$ & $\begin{array}{c}144 \\
(73.7) \\
\end{array}$ & $\begin{array}{c}51 \\
(26.3) \\
\end{array}$ & $\begin{array}{c}0 \\
(0.0)\end{array}$ & $\begin{array}{c}60 \\
(57.2) \\
\end{array}$ & $\begin{array}{c}39 \\
(37.2) \\
\end{array}$ & $\begin{array}{c}6 \\
(5.6) \\
\end{array}$ & 52.2 & 0.001 \\
\hline $\begin{array}{l}\text { - Satisfactory } \\
\text { housekeeping }\end{array}$ & $\begin{array}{c}142 \\
(72.8)\end{array}$ & $\begin{array}{c}35 \\
(17.9)\end{array}$ & $\begin{array}{c}18 \\
(9.3)\end{array}$ & $\begin{array}{c}58 \\
(55.2)\end{array}$ & $\begin{array}{c}31 \\
(29.5)\end{array}$ & $\begin{array}{c}16 \\
(15.3)\end{array}$ & 6.3 & 0.04 \\
\hline $\begin{array}{l}\text { Understanding from } \\
\text { husband }\end{array}$ & $\begin{array}{c}36 \\
(18.5)\end{array}$ & $\begin{array}{c}79 \\
(40.5)\end{array}$ & $\begin{array}{c}80 \\
(41.0)\end{array}$ & $\begin{array}{c}12 \\
(11.3)\end{array}$ & $\begin{array}{c}25 \\
(23.8)\end{array}$ & $\begin{array}{c}68 \\
(64.9)\end{array}$ & 11.6 & 0.003 \\
\hline
\end{tabular}

* low or not considered as a challenge

\section{Table 4: Methods of coping with challenges}

\begin{tabular}{|c|c|c|c|c|c|}
\hline Methods of coping & $\begin{array}{l}\text { Women with } \\
\text { shift work } \\
\begin{array}{c}(n=195) \\
N(\%)\end{array}\end{array}$ & $\begin{array}{c}\text { Women } \\
\text { without shift } \\
\text { work ( } n=105) \\
N(\%)\end{array}$ & $\begin{array}{c}\begin{array}{c}\text { Total } \\
(\mathrm{n}=300)\end{array} \\
N(\%)\end{array}$ & $x^{2}$ & $\begin{array}{c}P \\
\text { value }\end{array}$ \\
\hline - Decision of small family size & $161(65.18)$ & $86(34.82)$ & $247(82.3)$ & 0.02 & 0.89 \\
\hline $\begin{array}{l}\text { - Recruitment of babysitter/ } \\
\text { housekeeper }\end{array}$ & $155(67.69)$ & $74(32.31)$ & $229(76.3)$ & 3.07 & 0.08 \\
\hline - Participation in family income & $124(66.67)$ & $62(33.33)$ & $186(62.0)$ & 0.60 & 0.44 \\
\hline $\begin{array}{l}\text { Selection of potentially non- } \\
\text { emergency specialty. }\end{array}$ & $32(31.07)$ & $71(68.93)$ & $103(34.3)$ & 79.38 & 0.001 \\
\hline $\begin{array}{l}\text { - Living near the workplace } \\
\text { (e.g., } \\
\text { PHC housing facility }\end{array}$ & $36(57.14)$ & $27(42.86)$ & $63(21.0)$ & 2.16 & 0.14 \\
\hline - Taking unpaid vacation & $35(74.47)$ & $12(25.53)$ & $47(15.7)$ & 2.20 & 0.14 \\
\hline
\end{tabular}

\section{REFERENCES}

1. Lorber J. Why women physicians will never be true equals in the American medical profession. In: Riska E, Wegar $\mathrm{K}$, eds. Gender, work and medicine. Women and the medical division of labour. London: Sage Studies in International Sociology; 1993.62-76.

2. Frank E, McMurray JE, Linzer M, Elon L. Career satisfaction of US women physicians, results from he Women Physicians' Health Study. Arch Intern Med. 1999; 159: 1417-26. 
3. Egyptian Ministry of Health official website: www.mohp.org.eg Accessed September 2007.

4. Egyptian Ministry of Higher Education official web site: www.egymhe.gov.eg. Accessed September 2007.

5. Arnetz BB. Psychosocial challenges facing physicians of today. Social Science \& Medicine. 2001; 52 (2): 20313.

6. Laine C. On being Dr. Mom. JAMA. 1998; 129 (7): 579-80.

7. Keeton K, Fenner DE, Johnson TRB, Hayward RA. Predictors of physician career satisfaction, work-life balance, and burnout. Obstetrics \& Gynecology. 2007; 109 (4): 949-55.

8. Potee RA, Gerber AJ, Ickovics JR. Medicine and motherhood: shifting trends among female physicians from 1922 to 1999. Academic Medicine. 1999; 74 (8): 911-9.

9. Johnson JV, Hall EM, Ford DE, Mead LA, Levine DM, Wang NY, et al. The psychosocial work environment of physicians: the impact of demands and resources on job dissatisfaction and psychiatric distress in a longitudinal study of John Hopkins Medical School graduates. Occup Environ Med. 1995; 37:1151-9.

10. Robinson GE. Career satisfaction in female physicians. JAMA. 2004; 291:635.

11. Kværner K, Aasland O, Botten G. Female medical leadership: crosssectional study. BMJ. 1999;318:91-4.

12. Lyness KS, Thompson DE. Above the glass ceiling? A comparison of matched samples of female and male executives. J Appl Psychol. 1997; 82: 359-75.

13. Ramirez AJ, Graham J, Richards MA, Cull A, Gregory WM. Mental health of hospital consultants: the effects of stress and satisfaction at work. Lancet. 1996; 347: 724-8.

14. Deckard G, Meterko M, Field D. Physician burnout: an examination of personal professional and organizational relationships. Med Care. 1994; 32:745-54.

15. Hofoss D, Gjerberg E. Physicians' working hours. Tidsskr Nor Laegeforen. 1994; 114: 3059-63.

16. Firth-Cozens J, Moss F. Hours, sleep, teamwork, and stress [editorial]. BMJ. 1998;317:1335-6.

17. Kivimaki $M$, Sutinen $R$, Elovaino $M$, Vahtera J, Rasanen K, Töyry S, et al. Sickness absence in hospital physicians: 2 year follow up study on determinants. Occup Environ Med. 2001;58: 361-6.

18. Egyptian Ministry of Manpower and Emigration. Official website: www.emigration.gov.eg. Accessed 25 November 2007.

19. El-Mouelhy M. Violence against Women: A public health problem. J Primary Prevention. 2004, 25 (2): 289303.

20. Wiers-Jenssen J, Vaglum $P$, Ekeberg O. Career plans of future physicians. Level of ambition and plans for specialization among medical students. Tidsskr Nor Laegeforen. 1997; 117: 2807-11.

21. Fortinsky R, Youngner S, Landefeld CS. When doctors marry doctors: A survey exploring the professional and family lives of young physicians. JAMA. 1999; 130 (4): 312-9.

22. Brotherton SE, LeBailly SA. The effect of family on the work lives of married physicians: what if the spouse is a physician, too? J Am Med Womens Assoc. 1993; 48: 175-81.

23. Levinson W, Kaufman K, Clark B, Tolle SW. Mentors and role models for women in academic medicine. West $\mathrm{J}$ Med. 1991; 154: 423-6. 